records of Koenigia, Diapensia and Artemisia norvegica) some may choose to ruminate on the number and likely identity of species yet to be discovered here. Palynologists, geologists and archæologists will also find, in these pages, the sort of information that can save hours of exhausting work in the identification of doubtful grains or fragments. Two features that will certainly not be commended by botanists are the absence of author citations in the main body of the text, and the invention of popular names, some of which (for example, "Boreal Blinking-chickweed") would, in a less august environment, raise a laugh. It is a pity, too, that space should have been devoted to derivations of generic names; such learning is scarcely called for in a book of this sort. The illustrations, though uneven in quality, are on the whole very pleasant to look at, and sufficiently detailed to give us a very fair idea of each plant. Printing and format are excellent, though the regrettably high price must necessarily put the book beyond the means of many who would be happy to possess it.

R. D. MEIKLE

\section{NEW IDEAS FOR INDUSTRY}

Investment in Innovation

By C. F. Carter and B. R. Williams. Pp. ix +167 . (London: Oxford University Press, 1958.) 15s. net.

7 Thint HIS book is in effect a supplement to the same authors' work on industry and technical progress, being in the main a by-product of the case studies which were undertaken in connexion with the writing of that book under the auspices of the British Association and the Conditional Aid scheme. It is a detailed investigation, based upon case material, of the reasons why firms invest or do not invest in technical innovations. Perhaps the only brief statement that can be made about its conclusions is that it shows the enormous range of difference between firms and industries in the nature of the incentives to investment. Thus, for example, it is made clear that, in some cases, keener competition at home or abroad is an incentive to investment while in other cases protection from competition will have this effect. The effect of excess demand manifesting itself in long order books is also noted as one of the factors that have been important in some cases in recent years, and there is a careful discussion of the effect of fiscal changes in stimulating either new investment or quicker replacement of plant. The general factors which are regarded as likely to promote accelerated investment in innovations most effectively, however, soem to be the supply and wide diffusion through industry of scientifically literate people and the improvement of recruitment and training for management. It is essentially effective access to information about new technical possibilities and the willingness and ability to introduce change without creating insuperable opposition that seem to be key factors in determining the rate of industrial progress.

Not very much attention is given by the authors to the supply of capital as a factor limiting investment of the relevant kind, though they found some cases in which shortage of risk capital had been important. Their investigation, however, throws more light on the old question whether interest rate is an important controlling factor governing industrial investment. In general, they conclude from their field studies that with interest rates varying over the normal range their direct influence is slight-investment projects are either so attractive that a difference in interest rate between, say, 2 and 6 per cent will have little effect upon them or so unattractive that they will not be undertaken at any interest rate however low. The authors think, however, that there is an intermediate class of projects to which the rate of interest is critical even as things are, and that this class might be much bigger if interest rates were capable of going higher than in fact they have gone in advanced countries in modern times.

Altogether this is an extremely valuable and stimulating book belonging to the select but growing class of contributions to economics which seek answers to the really fundamental questions from direct investigation of industrial life.

\section{A. J. BRown}

\section{THE FUTURE OF THE ETRUSCANS}

\section{Ciba Foundation Symposium on Medical Biology} and Etruscan Origins

Edited by G. E. W. Wolstenholme and Cecilia M. O'Connor. Pp. xii +255. (London: J. and A. Churchill, Ltd., 1959.) 45s. net.

7 HE publication of a Ciba Foundation symposium is always an interesting event. This volume has a stimulating title; the synthesis attempted is an innovation of some significance, and it will be viewed from many quarters with a critical eye, in order to assess the value of its application to populations other than the Etruscans.

The Foundation must be congratulated on having drawn together a group of eminent scientists and Etruscologists, and on the clear layout and attractive presentation of the volume. The illustrations show evidence of a care not always extended to the maps. The first five papers presented at the symposium give the evidence of archæology, religion and linguistics, and some space is given to discussion of the varying theories on the origins of the Etruscans which this evidence permits. As Prof. Banti points out, no one theory can be held dogmatically on the basis of the present information from these fields; and for this reason if for no other, much might be expected of the contributions of the scientists to this meeting. If, in the conclusions which may be drawn from it, the second section falls short of the reader's expectations, it must be borne in mind that the value of scientific work to such studies has only recently been appreciated; indeed, this is made clear in the discussions, in which it is admitted that skeletal material has received cavalier treatment in the past. The main value of this meeting of scientists and archæologists lies in its promise, and in the opportunity it has provided to discuss mutual requirements; many interesting possibilities are outlined by the various speakers, not the least of which is that of the blood grouping of skeletal remains. Several speakers discuss the serology of the modern population of Etruria ; a feature the impact of which is somewhat spoilt by the failure of the historians to show that this region has remained genetically isolated since the Etruscan period.

This book presents an intriguing approach to an old and fascinating problem, and much can be gained from its careful outline of the requirements and pitfalls of such studies. It is likely to become a useful reference book. MadeleINE SMITH 